\title{
Порівняльний аналіз результатів лікування хворих з кардіоміопатією, що перебувають у листі очікування трансплантації серця залежно від етіології захворювання та обраного методу лікування
}

\begin{abstract}
Резюме. У роботі проаналізовано результати 1-річного проспективного спостереження 166 хворих з різними формами кардіоміопатій, що перебувають у листі очікування трансплантації серця залежно від етіології захворювання та проведеного методу лікування.

При проведенні хірургічної корекції скоротливої функції серця у хворих з ішемічною кардіоміопатією (ІКМП) шанси на виживання впродовж 1-го року підвищувались у 1,636 та у 1,667 раза за умови доповнення консервативного лікування хірургічним (коронарне шунтування (КШ) та стентування коронарних артерій), у 6 разів при доповненні консервативного лікування трансплантації стовбурових клітин пуповинної крові (ТСКПК). Було встановлено ефективність комплексної терапії ІКМП із додаванням стовбурових клітин, доведено зниження серцево-судинної та загальної смертності на 10 \%, проти групи, де застосовувалась консервативна терапія, зниження смертності на 18,9 \% порівняно з КШ, на 18,6 \% - порівняно зі стентуванням. Доведено, що 1-річна летальність серед пацієнтів з дилатаційною кардіоміопатією знижується на 15 \% при доповненні консервативного лікування ТСКПК. Натомість результати лівошлуночкової вентрикулопластики за Батистою за показником 1-річної летальності були незадовільними.
\end{abstract}

Ключові слова: хронічна серцева недостатність, ішемічна кардіоміопатія, дилатаційна кардіоміопатія.

Серцева недостатність є важливою медичною, соціальною та економічною проблемою, яка охоплює понад 23 млн громадян по всьому світу [1].

Найчастішими причинами хронічної серцевої недостатності $(\mathrm{XCH})$ в Європі, а також у нашій країні, в останні роки стали ішемічна хвороба серця (IXC) та інфаркт міокарда (IM), які спостерігаються у 60-70 \% стаціонарних хворих та асоціюються насамперед із порушенням систолічної функції лівого шлуночка. Серед інших причин розвитку ХСН слід зазначити дилатаційну кардіоміопатію (ДКМП) та ревматичну хворобу серця [2].

Трансплантація серця (ТC) є найрадикальнішим методом лікування хворих 3 термінальною стадією ХСН. Виживаність хворих після ТС за рахунок вдосконалення техніки збереження донорського серця та імуносупресивної терапії поліпшується, а кількість хворих у листі очікування ТС, прогресивно збільшується впродовж останнього десятиліття. Основною причиною відносно сталого числа ТС, є обмежена кількість донорських сердець [3].

Ураховуючи вищезазначене, у світі відбувається постійний пошук альтернативних методів, які б дозволили подовжити тривалість життя пацієнтів з рефрактерною стадією серцевої недостатності та покращити iї якість.
Коронарна реваскуляризація є одним з найбільш адекватних методів відновлення скоротливої здатності лівого шлуночка та функціональних можливостей міокарда при ішемічному генезі ХCH [4].

Лікування серцевої недостатності ішемічного генезу за відсутності стенокардії, з огляду на відсутність рандомізованих контрольованих досліджень у цій вибірці пацієнтів, становить проблему. I хоча, у деяких рандомізованих дослідженнях вивчалася ефективність реваскуляризації міокарда в поєднанні з хірургічною реконструкцією лівого шлуночка з метою зворотного ремоделювання, ймовірність покращення скоротливості міокарда та підвищення фракції викиду (ФВ) лівого шлуночка є низькою [4, 5].

При ДКМП консервативна терапія, яку проводять згідно з наявними рекомендаціями, також не покращує скоротливу функцію лівого шлуночка. Серед можливих хірургічних втручань операція Батиста може підвищувати якість життя в пацієнтів у термінальній стадії ДКМП на нетривалий період. Однак після низки досліджень вона не рекомендується для виконання у зв'язку з низькою ефективністю та високою летальністю [6].

На думку деяких авторів, перспективним напрямом у лікуванні ХCH є клітинна терапія. Проте клінічних даних відносно ефективності та безпеки застосування 


\section{Таблиця 1}

Аналіз летальності у хворих з ІКМП, що перебувають у листі очікування трансплантації серия за 12 місяців спостереження

\begin{tabular}{|c|c|c|c|c|c|}
\hline Метод лікування & $\begin{array}{l}\text { Кількість } \\
\text { пацієнтів }\end{array}$ & $\begin{array}{c}\text { Кількість летальних } \\
\text { випадків }\end{array}$ & $A R, \%$ & OR & $\begin{array}{c}\text { Cumulative Odds Ratio } \\
(95 \% \mathrm{Cl})\end{array}$ \\
\hline Консервативна терапія & 20 & 6 & 30,0 & 1,0 & \multirow{4}{*}{$\begin{array}{c}1,87 \\
{[0,99-3,49]}\end{array}$} \\
\hline КШ & 38 & 4 & 10,5 & 0,61 & \\
\hline Стентування КА & 35 & 4 & 11,4 & 0,60 & \\
\hline Реваскуляризація + ТСКПК & 20 & 1 & 5,0 & 0,16 & \\
\hline
\end{tabular}

Мантеля - Хенцеля $\chi^{2}-3,834(p=0,050)$

стовбурових клітин у хворих з резистентною ХСН у комплексній корекції скоротливої функції лівого шлуночка є недостатньо [7-9].

Мета роботи - проаналізувати результати лікування хворих з кардіоміопатією, що перебувають на листі очікування трансплантації серця залежно від етіології захворювання та проведеного методу лікування.

Матеріали та методи. У роботі було розглянуто результати 1-річного проспективного спостереження в пацієнтів із ХCH, які перебували у листі очікування ТС і яким застосовували різні методи лікування. У клінічному дослідженні брало участь 166 хворих, які були розділені на дві підгрупи за етіологічним принципом хворі з ішемічною кардіоміопатією (ІКМП) $(\mathrm{n}=113)$ і ДКМП $(\mathrm{n}=53)$. У свою чергу кожна група була розділена на підгрупи залежно від методу лікування. Хворі з ДКМП входили в групу, де проводилося лікування за допомогою трансплантації стовбурових клітин пуповинної крові (ТСКПК) $(\mathrm{n}=20)$ і в групу порівняння хворі, яким була виконана операція Батисти $(\mathrm{n}=33)$. У групі з ІКМП виділені підгрупи пацієнтів, яким виконували коронарне шунтування (КШ) $(\mathrm{n}=35)$, стентування коронарних артерій (KA) $(\mathrm{n}=38)$, реваскуляризацію в поєднанні з ТСКПК $(n=20)$, і пацієнти, які отримували тільки медикаментозну терапію $(\mathrm{n}=20)$. Трансплантацію стовбурових клітин пуповинної крові проводили шляхом внутрішньовенного краплинного введення препарату «Кріоконсервована пуповинна кров людини». Кількість клітин у загальному об'ємі від $0,890 \times 10^{9}$ до $0,950 \times 10^{9}$; кількість мононуклеарів: від $0,486 \times 10^{9}$ до $0,520 \times 10^{9}$; CD34+ клітин - не менше $1,0 \pm$ $0,01 \times 10^{9} /$ мл. Хворих в обох групах можна було порівняти за основними клінічними показниками і вони достовірно не розрізнялися між собою. Здійснювали статистичну обробку даних летальності та ефективності лікування залежно від проведеного методу терапії.

Оцінювання ефективності лікування проводили 3 урахуванням наслідків лікування, абсолютного (AR Absolute Risk) та відносного (RR - Relative Risk) терапевтичних ефектів, терапевтичної користі - різниці абсолютного ризику (ARR - Absolute Risk Reduction), також відношення шансів (OR, odds ratio) з розрахун- ком довірчих інтервалів та критерію достовірності щодо RR та OR. Аналіз вірогідності настання результату, що вивчається, виконували за методом Каплана - Мейєра.

Результати та їх обговорення. Упродовж періоду спостереження у 33,9 \% хворих виникли гострі серцевосудинні ускладнення (летальні випадки та декомпенсація ХCH) у $67 \%$ - хронічні ускладнення (повторна госпіталізація, розвиток кардіоренального синдрому).

Ризик загальної та кардіальної смертності при ІКМП залежав від лікувальної тактики.

Під час аналізу ефективності лікування (консервативного, КШ, стентування та поєднане застосування реваскуляризації міокарда з ТСКПК) були отримані результати, наведені в таблиці 1.

Як бачимо, впродовж 12 місяців спостереження абсолютний ризик загальної та серцево-судинної летальності становив $30 \%$ у групі консервативної терапії, 10,5 \% при застосуванні КШ та 11,4 \% при стентуванні коронарних артерій, що було на 25, 5,5 та 6,5\% вище, ніж при комплексному застосуванні реваскуляризації та ТСКПК. Однак незважаючи на зменшення odds ratio від 1,0 (консервативна терапія) до 0,61 (КШ), 0,60 (стентування), сягаючи 0,16 при ТСКПК у хворих з ІКМП, різниця за Cumulative Odds Ratio 1,87 [0,993,49 ] та $\chi^{2}$ Мантеля - Хенцеля була невірогідною.

Тому нами було проведено зіставлення кожної 3 груп відносно групи пацієнтів, де застосовувалась ТСКПК (таблиця 2).

Порівнюючи ефективність терапії стовбуровими клітинами пуповинної крові при IКМП, було доведено зниження серцево-судинної та загальної смертності до $5 \%$, з вірогідними значеннями відносного ризику 2,5 $[0,97-16,6]$ та відношення шансів $6,00[1,08-33,3]$ проти групи, де застосовувалась консервативна терапія.

При зіставленні ефективності аорто-коронарного шунтування без ТСКПК та хірургічної реваскуляризації з ТСКПК при ІКМП було доведено зниження серцево-судинної та загальної смертності на $5,5 \%$, RR $1,05[0,71-11,8]$, OR - 3,67 [0,73-18,5], p > 0,05.

Під час аналізу рівня річної летальності у хворих 3 ІКМП при проведенні стентування КА проти комп- 
Габрієлян А. В. / Порівняльний аналіз результатів лікування хворих з кардіоміопатією, що перебувають...

\section{Таблиця 2}

Порівняльне оцінювання ефективності терапіі стовбуровими клітинами проти інших методів лікування

\begin{tabular}{|c|c|c|c|c|}
\hline Метод лікування & AR, \% & ARR & $\mathbf{R R}$ & OR \\
\hline $\begin{array}{l}\text { Консервативна } \\
\text { терапія }\end{array}$ & 30,0 & \multirow{2}{*}{25,0} & \multirow{2}{*}{$\begin{array}{c}2,5 \\
{[0,97-16,6]}\end{array}$} & \multirow{2}{*}{$\begin{array}{c}6,0 \\
{[1,08-33,3]}\end{array}$} \\
\hline $\begin{array}{l}\text { Реваскуляризація + } \\
\text { ТСКПК }\end{array}$ & 5,0 & & & \\
\hline КШ & 10,5 & \multirow[b]{2}{*}{5,5} & \multirow{2}{*}{$\begin{array}{c}1,05 \\
{[0,71-11,8]}\end{array}$} & \multirow[b]{2}{*}{$\begin{array}{c}3,67 \\
{[0,73-18,5]}\end{array}$} \\
\hline $\begin{array}{l}\text { Реваскуляризація + } \\
\text { ТСКПК }\end{array}$ & 5,0 & & & \\
\hline Стентування КА & 11,4 & \multirow[b]{2}{*}{6,4} & \multirow{2}{*}{$\begin{array}{c}1,14 \\
{[0,69-11,7]}\end{array}$} & \multirow{2}{*}{$\begin{array}{c}3,60 \\
{[0,70-18,5]}\end{array}$} \\
\hline $\begin{array}{l}\text { Реваскуляризація + } \\
\text { ТСКПК }\end{array}$ & 5,0 & & & \\
\hline
\end{tabular}

лексного застосування реваскуляризації з ТСКПК були отримані результати, які показують, що абсолютний ризик загальної та серцево-судинної летальності зменшився на $6,4 \%$, відносний ризик становив $-1,14$ [0,69-11,7], відношення шансів - 3,60 [0,70-18,5].

Для оцінювання ефективності лікування (консервативного та хірургічного) у хворих з ІКМП був проведений аналіз спостереження з оцінюванням шансів 1-річної виживаності (таблиця 3).

Зіставлення чотирьох груп та сумарний аналіз вірогідності 1-річної виживаності показав, що шанси виживаності у хворих з ІКМП впродовж 1-го року підвищуються у 1,6 та 1,7 раза при доповненні консервативного лікування хірургічним (КШ та стентування KA), у 6 разів при доповненні консервативного лікування процедурою ТСКПК. Також шанси зменшення 1-річної летальності становлять 3,7 та 3,60 раза при доповненні хірургічного лікування (КШ та стентування KA) процедурою трансплантації.

Ризик загальної та кардіальної смертності при ДКМП також залежав від лікувальної тактики (таблиця 4).

Як бачимо, впродовж 12 місяців спостереження абсолютний ризик загальної та серцево-судинної летальності становив $30 \%$ у групі консервативної терапії, 54,5 \% при застосуванні вентрикулопластики за Батистою та $15 \%$ при ТСКПК. В останньому випадку це було на $15 \%$ та 29,5\% нижче, ніж у разі консервативного та хірургічного лікування. Шанси 1-річної летальності при застосуванні методу Батисти збільшувались в 2,80 раза навіть при порівнянні з консервативною терапією. Але при множинному порівнянні Cumulative Odds Ratio 1,575 [0,68-3,67] та $\chi^{2}$ Мантеля - Хенцеля були невірогідними.

Результати проведеного нами зіставлення груп консервативного та хірургічного лікування відносно групи пацієнтів, де застосовувалась ТСКПК, наведено в таблиці 5.

\section{Таблиця 3}

Однорічна виживаність у хворих з ІКМП

\begin{tabular}{lccc} 
Метод лікування & OR & $\chi^{2}$ & p \\
\hline Консервативна терапія vs. КШ & 1,636 & 0,717 & 0,397 \\
\hline $\begin{array}{l}\text { Консервативна терапія vs. Стенту- } \\
\text { вання КА }\end{array}$ & 1,667 & 0,746 & 0,388 \\
\hline $\begin{array}{l}\text { Консервативна терапія vs. } \\
\text { Реваскуляризація + ТСКПК }\end{array}$ & 6,0 & 5,063 & 0,024 \\
\hline КШ vs. Стентування КА & 1,019 & 0,001 & 0,972 \\
\hline КШ vs. Реваскуляризація + ТСКПК & 3,667 & 2,992 & 0,084 \\
\hline $\begin{array}{l}\text { Стентування КА vs. Реваскуляри- } \\
\text { зація + ТСКПК }\end{array}$ & 3,60 & 2,823 & 0,093
\end{tabular}

\section{Таблиця 4}

Аналіз летальності у хворих з ДКМП, що перебувають у листі очікування трансплантації серия за 12 місяців спостереження

\begin{tabular}{|c|c|c|c|c|c|}
\hline $\begin{array}{l}\text { Метод } \\
\text { лікування }\end{array}$ & $\begin{array}{l}\text { Кількість } \\
\text { пацієнтів }\end{array}$ & $\begin{array}{c}\text { Кількість } \\
\text { леталь- } \\
\text { них } \\
\text { випадків }\end{array}$ & $\begin{array}{c}\text { AR, } \\
\%\end{array}$ & OR & $\begin{array}{c}\text { Cumulative } \\
\text { Odds Ratio } \\
\text { (95\% CI) }\end{array}$ \\
\hline $\begin{array}{l}\text { Консерватив- } \\
\text { на терапія }\end{array}$ & 20 & 6 & 30,0 & 1,0 & \multirow{3}{*}{$\begin{array}{c}1,575 \\
{[0,68-3,67]}\end{array}$} \\
\hline $\begin{array}{l}\text { Вентрикуло- } \\
\text { пластика }\end{array}$ & 33 & 18 & 54,5 & 2,80 & \\
\hline ТСКПК & 20 & 3 & 15,0 & 0,412 & \\
\hline
\end{tabular}

Мантеля - Хенцеля $\chi^{2}-7,97(p<0,05)$

\section{Таблиця 5}

Порівняльне оцінювання ефективності терапії стовбуровими клітинами проти консервативної терапії та лівошлуночкової вентрикулопластики за рівнем річної летальності при ДКМП

\begin{tabular}{|c|c|c|c|c|}
\hline Метод лікування & $A R, \%$ & ARR & $\mathbf{R R}$ & OR \\
\hline $\begin{array}{l}\text { Консервативна } \\
\text { терапія }\end{array}$ & 30,0 & \multirow{2}{*}{15,0} & \multirow{2}{*}{$\begin{array}{c}2,00 \\
{[0,57-6,91]}\end{array}$} & \multirow{2}{*}{$\begin{array}{c}2,43 \\
{[0,51-11,5]}\end{array}$} \\
\hline ТСКПК & 15,0 & & & \\
\hline & $A R, \%$ & ARR & $\mathbf{R R}$ & OR \\
\hline Вентрикулопластика & 54,5 & \multirow[t]{2}{*}{40,0} & \multirow{2}{*}{$\begin{array}{c}3,64 \\
{[1,22-10,8]}\end{array}$} & \multirow{2}{*}{$\begin{array}{c}6,80 \\
{[1,67-27,7]}\end{array}$} \\
\hline ТСКПК & 15,0 & & & \\
\hline
\end{tabular}

Порівнюючи ефективність терапії стовбуровими клітинами пуповинної крові з консервативною терапією при ДКМП, було доведено зниження серцево-судинної та загальної смертності на $15 \%$, зі значеннями відносного ризику та відношення шансів 2,00 [0,57$6,91]$ та 2,43 [0,51-11,5] проти групи, де застосовувалась консервативна терапія.

При зіставленні ефективності ТСКПК з лівошлуночковою вентрикулопластикою при ДКМП було до- 


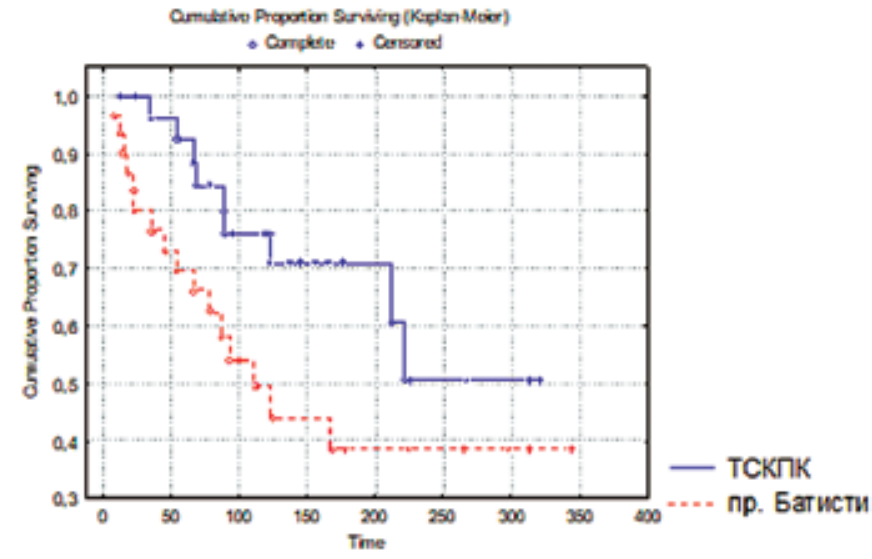

Рисунок 1. Зіставлення даних виживаності у хворих 3 ДКМП: А - ТСКПК; В - лівошлуночкова вентрикулопластика за Батистою

ведено зниження серцево-судинної та загальної смертності на $39,5 \%$, з вірогідними показниками відносного ризику $(3,64[1,22-10,8])$ та відношення шансів $(6,80$ $[1,67-27,7])$.

Тобто 1-річна летальність серед пацієнтів з ДКМП знижується на 15 \% при доповненні консервативного лікування процедурою трансплантації. Натомість, результати лівошлуночкової вентрикулопластики за Батистою за показником 1-річної летальності були незадовільними.

Узагальнюючи випадки незадовільних результатів в обох групах - ішемічної та дилатаційної кардіоміопатії, ми проаналізували випадки летальності та показники виживаності у зазначених групах при всіх методах лікування, які вивчались за методом Каплана - Мейера.

При порівнянні кривих виживаності Каплана Мейера в групі хворих з ДКМП при ТСКПК та операції Батисти, встановлено зниження ризику смерті, незалежно від причин летальних випадків після трансплантації (рисунок 1). Різниця за виживаністю була вірогідною. Зміни виживаності та «пік» летальності залежали також від періоду спостереження. Зокрема в перші 6 місяців, виживаність у групі лівошлуночкової вентрикулопластики становила 58,2 \%, знижуючись до $38 \%$ за експонентою у віддаленому періоді. Тому ми не можемо рекомендувати операцію Батисти для лікування хворих з ДКМП у зв'язку з високою летальністю, зокрема в ранній період спостереження.

Показники виживаності пацієнтів з ДКМП після процедури ТСКПК є вищими, ніж показники виживаності у хворих, яким проведено операцію Батисти. Ці дані переконливо свідчать про те, що ТСКПК дає змогу збільшити термін життя пацієнтів з ДКМП та може використовуватись як самостійний метод лікування

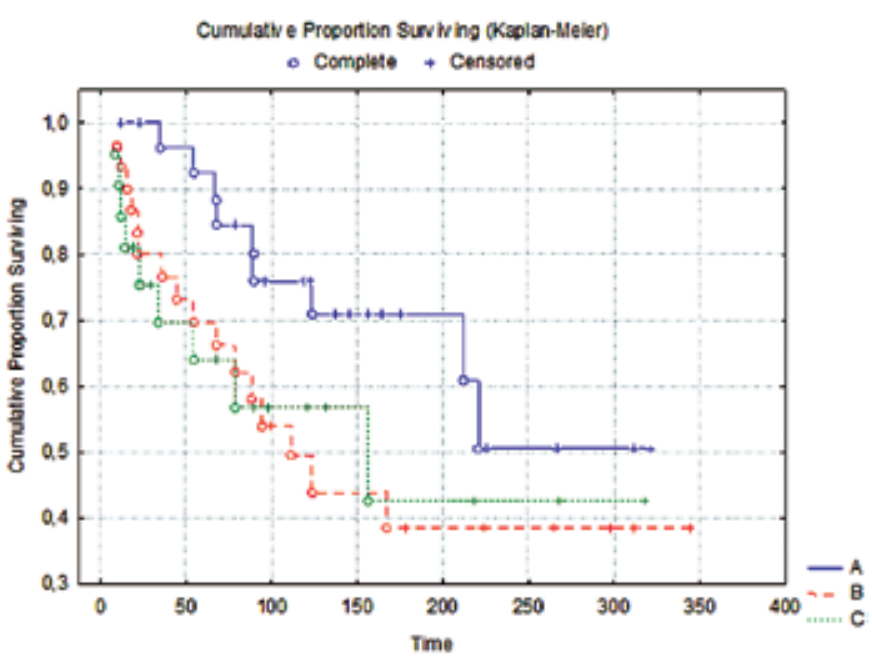

Рисунок 2. Зіставлення даних виживаності у хворих з ІКМП: A - комплексне лікування із застосуванням ТСКПК на фоні хірургічного лікування; $B$ - коронарне шунтування;

C - стентування KA

для комплексної корекції скоротливої функції лівого шлуночка.

Дещо інші рекомендації можна запропонувати для пацієнтів з ІКМП. Основною відмінністю є те, що при ДКМП процедура трансплантації використовувалась як ізольований метод на фоні лише консервативної терапії. Натомість, при ІКМП процедура ТСКПК доповнювала такі базові методики, як коронарне шунтування та стентування коронарних артерій.

Криві виживаності наведені на рисунку 2.

Встановлено вірогідну різницю між групами $\mathrm{p}=$ 0,046 за рахунок кращих результатів при комплексному застосуванні СКПК на фоні хірургічного лікування.

Під час аналізу кривих виживаності при ІКМП принципової вірогідної різниці між ефективністю процедури КШ або стентування не було отримано.

Ураховуючи отримані дані, можна стверджувати, що за наявності хронічної ішемії міокарда, ускладненої ІКМП із серцевою недостатністю, передусім потрібно провести процедури, спрямовані на відновлення коронарного кровотоку, проте найефективнішою є комплексна корекція скоротливої функції лівого шлуночка, а саме: застосування хірургічної корекції за рахунок реваскуляризації та додаткове проведення ТСКПК.

Таким чином, власні результати комплексного лікування хворих з ХСН показали, що ТСКПК є безпечною процедурою та добре переноситься.

Отримані дані зіставляються з дослідженнями інших авторів [7-10]. Зокрема в роботі Джолдасбекової А. У. та співавт. була показана висока ефективність та безпечність трансплантації стовбурових клітин. У 
цій роботі зазначається, що в жодного хворого після трансплантації стовбурових клітин не було відзначено розвитку онкологічних захворювань, імунних реакцій, загострення запальних захворювань, які загрожують порушенню ритму серця, погіршенню перебігу хронічної ішемії міокарда, розвитку або прогресуванню ХСН. Натомість, на тлі клітинної терапії зменшувалась порожнина лівого шлуночка, покращувалась систолічна функція міокарда, знижувався функціональний клас ХCH за NYHA, що підтверджувалося вірогідним зниженням раннього біологічного маркера серцевої недостатності - натрійуретичного пептиду [10].

\section{Висновки}

1. Комплексний підхід до корекції скоротливої функції лівого шлуночка - хірургічна реваскуляризація з ТСКПК при ІКМП або ТСКПК в поєднанні із сучасною медикаментозною терапією при ДКМП сприяє вірогідному зниженню проявів ХСН, підвищенню скоротливої здатності міокарда, покращенню якості життя пацієнтів.

2. Диференційований підхід до лікування хворих 3 різними формами кардіоміопатій дає можливість ефективно впливати на прояви серцевої недостатності і може застосовуватися як місток до трансплантації серця.

\section{Список використаних джерел References}

1. liu L, Eisen HJ. Epidemiology of heart failure and scope of the problem. Cardiology Clinics. 2014;32:1-8. https://doi. org/10.1016/j.ccl.2013.09.009

2. Kenchaiah S, Vasan RS. Heart Failure in Women--Insights from the Framingham Heart Study. Cardiovasc. Drugs Ther. 2015 Aug;29(4):377-90. https://doi.org/10.1007/ s10557-015-6599-0

3. Brangerand P, Samuel U, editors (Eurotransplant International Foundation). Annual report 2018. Leiden:
Eurotransplant Foundation; III., graf., tab; 2019 May. Available from: https://www.eurotransplant.org/cms/ index.php?page $=$ annual_reports

4. Anavekar NS, Chareonthaitawee P, Narula J, Gersh BJ. Revascularization in Patients With Severe Left Ventricular Dysfunction: Is the Assessment of Viability Still Viable? JACC. 2016;67(24):2874-87. https://doi.org/10.1016/j. jacc.2016.03.571

5. Jolicœur EM, Dunning A, Castelvecchio S, Dabrowski R, Waclawiw MA, Petrie MC, et al. Importance of Angina in Patients With Coronary Disease, Heart Failure, and Left Ventricular Systolic Dysfunction Insights From STICH. JACC. 2015;66(19):2092-100. https://doi.org/10.1016/j. jacc.2015.08.882

6. Chachques JC. Cardiomyoplasty: Is it still a viable option in patients with end-stage heart failure? European Journal of Cardio Thoracic Surgery. 2009; 35 (2): 201-3. https:// doi.org/10.1016/j.ejcts.2008.09.028

7. Vrtovec B. Cell Therapy for Nonischemic Cardiomyopathy: Current Status and Future Perspectives. Circ Res. 2018;122(1):28-30.

CIRCRESAHA. 117.312385

8. Fisher SA, Doree C, Mathur A, Taggart DP, MartinRendon E. Stem cell therapy for chronic ischaemic heart disease and congestive heart failure. Cochrane Database of Systematic Reviews. 2016;12:CD007888. https://doi. org/10.1002/14651858.CD007888.pub3

9. Medhekar SK, Shende VS, Chincholkar AB. Recent Stem Cell Advances: Cord Blood and Induced Pluripotent Stem Cell for Cardiac Regeneration - a Review. International Journal of Stem Cells. 2016;9(1):21-30. https://doi. org/10.15283/ijsc.2016.9.1.21

10. Dzholdasbekova A, Fedotovskikh G, Askarov M, Komsabakova B, Baigenzhina A, Kairatova A, et al. [Systemic administration of autologous mononuclear precultured bone marrow stem cells in heart failure]. Clinical Medicine of Kazakhstan. 2015;3(37):14-18. Russian.

\title{
Comparative analysis of cardiomyopathy patients in the waiting list for heart transplantology treatment results depending on a disease etiology and a selected method of treatment
}

\author{
Gabriyelyan A. V.
}

State Institute "Shalimov's National Institute of Surgery and Transplantation" to National Academy of Medical Sciences of Ukraine, Kyiv, Ukraine

\begin{abstract}
Introduction. In the paper we have conducted the efficiency evaluation of complex correction of heart pump function for patients with congestive heart failure (CHF) and patients with decreased left ventricular contractility being in the waiting list for heart transplantation, with continued 1-year long prospective observation.

Purpose. To analyze the treatment results of patients with cardiomyopathy being in the waiting list for heart transplantation depending on disease etiology and conducted method of treatment.

Materials and Methods. We have reviewed the results of 1-year prospective observation, including 166 patients with CHF against the background of Ischemic Cardiomyopathy (ICMP) (113 p.) or Dilated Cardiomyopathy (DCMP) (53 p.), being in the waiting list for heart transplantation. In the DCMP group, the Batisa left venticuloplasty (33 p.) and Cord Blood Stem Cells Transplantation (CBSCT (20 p.) transplantation has been performed. In the ICMPIC group 38 patients went through Coronary Artery Bypass Grafting (CABG), 35 - Coronary Artery Stenting (CAS), 20 patients in addition to revasculariza-
\end{abstract}


tion, went through CBSCT. The separate group of 20 people with the conservative therapy has been designated. Statistical data processing has been carried out.

Results and Discussion. Conducting the surgical correction of heart pump function for patients with ICMP, survival rate over the 1 year increased 1.636 and 1.667 times when conservative treatment supplemented with surgical one (CABG and CAS), and 6.0 times when conservative treatment supplemented with CABG. The effectiveness of complex therapy ICMP with the addition of Stem Cells has been revealed, $10 \%$ decrease of cardiovascular and general mortality has been proved over the group with conservative therapy, $18.9 \%$ mortality decrease compared to CABG, $18.6 \%$ - compared to Stenting. It has been proved, that 1-year mortality over the patients with DCMP decreases $15 \%$ while supplementing conservative treatment with CABG. On the other hand, the Batisa left venticuloplasty 1-year mortality results were unsatisfactory.

Conclusion. Complex differentiated approach towards the correction of left ventricular heart pump function for patients with different forms of Cardiomyopathy facilitates a likely decrease of CHF, increase of myocardium contractility, improve patient quality of life and can be used as a bridge to heart transplantation.

Keywords: chronicle heart failure, ischemic cardiomyopathy, dilated cardiomyopathy.

Стаття надійшла в редакцію 23.08.2019 р. 